\title{
Leptin modulates the expression of its receptors in the hypothalamic- pituitary-ovarian axis in a differential way
}

\author{
M P Di Yorio ${ }^{1,2}$, M G Bilbao ${ }^{1}$, M C Pustovrh ${ }^{1}$, J P Prestifilippo ${ }^{1}$ and A G Faletti ${ }^{1,2}$ \\ ${ }^{1}$ Centro de Estudios Farmacológicos y Botánicos (CEFYBO), Consejo Nacional de Investigaciones Científicas y Técnicas (CONICET)-Facultad de Medicina, UBA, \\ Paraguay 2155, $16^{\circ} \mathrm{P}, \mathrm{C} 1121 \mathrm{ABG}$ Buenos Aires, Argentina \\ ${ }^{2}$ Dpto. de Química Biológica, Facultad de Ciencias Exactas y Naturales (FCEyN), UBA, Cdad.Universitaria-Pabellón II-4 P, C1428EHA Buenos Aires, Argentina \\ (Correspondence should be addressed to A G Faletti; Email: agfaletti@yahoo.com.ar)
}

\begin{abstract}
To investigate the expression of leptin receptors $(\mathrm{Ob}-\mathrm{R})$ in the rat hypothalamus-pituitary-ovarian axis, immature rats were treated with eCG/hCG and Ob-R expression was evaluated by western blot analysis. The Ob-R expression increased $24 \mathrm{~h}$ after eCG administration in all the tissues assayed. In the hypothalamus, these levels immediately decreased to those obtained without treatment. In the pituitary, the $\mathrm{Ob}-\mathrm{R}$ expression continued to be elevated $48 \mathrm{~h}$ after eCG administration, whereas the hCG injection did not modify these levels. Similar results were obtained with the ovarian long isoform. To assess the effect of leptin on its receptors, $\mathrm{Ob}-\mathrm{R}$ was assessed in hypothalamus, pituitary and ovarian explants cultured in the presence or absence of leptin $(0 \cdot 3-500 \mathrm{ng} / \mathrm{ml})$. In the hypothalamus, we found a biphasic effect: the Ob-R expression was either reduced or increased
\end{abstract}

at low or high concentrations of leptin respectively. LH-releasing hormone secretion increased at $1 \mathrm{ng} / \mathrm{ml}$. In the pituitary, $\mathrm{Ob}-\mathrm{R}$ increased at 10 or $30 \mathrm{ng} / \mathrm{ml}$ of leptin for the long and short isoforms respectively. Leptin also induced an increase in $\mathrm{LH}$ release at $30 \mathrm{ng} / \mathrm{ml}$. In the ovarian culture, the presence of leptin produced an increase in Ob-R expression at different ranges of concentrations and a dosedependent biphasic effect on the progesterone production. In conclusion, all these results clearly suggest that leptin is able to modulate the expression of its own receptors in the reproductive axis in a differential way. Moreover, the positive or negative effect that leptin exerts on the ovulatory process may be dependent on this regulation.

Journal of Endocrinology (2008) 198, 355-366

\section{Introduction}

Initially, leptin was known to be a satiety hormone regulating both food intake and energy expenditure, but it is now known that this protein plays an important role in neuroendocrine signalling and reproduction. Leptin is mainly secreted from adipose cells and transported via blood to act in specific central and peripheral systems. Leptin is recognized by the leptin receptor (Ob-R; Tartaglia et al. 1995), which is a product of the $d b$ gene (Chen et al. 1996, Chua et al. 1996). Six leptin receptor isoforms generated by alternative splicing have been identified to date (Tartaglia 1997, Ahima 2000, Ahima \& Flier 2000). These isoforms fall into three categories: a long form (Ob-Rb), which contains all the intracellular motifs required for effective signalling via the JAK-STAT pathway; four truncated forms, namely Ob-Ra, $\mathrm{Ob}-\mathrm{Rc}, \mathrm{Ob}-\mathrm{Rd}$ and $\mathrm{Ob}-\mathrm{Rf}$, of which $\mathrm{Ob}-\mathrm{Ra}$ is the most physiologically significant and is considered to act merely as a transporter; and a secreted form (Ob-Re), which lacks both the intracellular and transmembrane domains, and serves as a plasmatic leptin-binding protein (Lee et al. 1996, Tartaglia 1997).
The reproductive function is regulated by the interaction of the hypothalamus, the pituitary and the gonads, which form the reproductive axis. The $\mathrm{Ob}-\mathrm{R}$ has been found all along the hypothalamus-pituitary-gonads (HPG) axis and several groups have demonstrated the presence of $\mathrm{Ob}-\mathrm{R}$ mRNA in endocrine tissue in the rat. In humans and rodents, different $\mathrm{Ob}-\mathrm{R}$ isoforms have been found to be widely distributed in many organs, including the hypothalamus (Mercer et al. 1996, Hoggard et al. 1997, Elmquist et al. 1998), the pituitary (Zamorano et al. 1997, Jin et al. 1999, 2000, Sone et al. 2001) and the ovary (Cioffi et al. 1996, 1997, Karlsson et al. 1997, Zamorano et al. 1997, Agarwal et al. 1999, Zachow et al. 1999, Duggal et al. 2002b).

Leptin is able to produce both stimulating (Ahima et al. 1997, Clément et al. 1998, Strobel et al. 1998, Almog et al. 2001, Barkan et al. 2005) and inhibitory (Zachow \& Magoffin 1997, Agarwal et al. 1999, Barkan et al. 1999, Brannian et al. 1999, Zachow et al. 1999, Duggal et al. 2000, 2002a) effects on the ovarian function. In previous studies, we found that ovulation is significantly inhibited by an acute treatment with leptin (Ricci et al. 2006). However, we have also observed that a chronic treatment with a low dose of this protein enhances 
the ovulatory process in comparison with control animals and partially prevents the negative effects produced by a severe malnutrition (Roman et al. 2005).

Although there is some evidence of leptin's ability to modulate HPG activity in the gonads and the pituitary, most of the information on this topic is concentrated on the mechanisms of leptin action within the central nervous system, especially on the hypothalamus.

Therefore, the objectives of the present study were to investigate the expression of leptin receptors in the rat HPO axis during the ovulatory process, and to assess whether different levels of leptin in this axis are able to modulate the expression of its receptors.

\section{Materials and Methods}

\section{Animals}

Adult female Sprague-Dawley rats with ten 15-day-old pups each were purchased from the School of Veterinarian Sciences (University of Buenos Aires, Argentina). Pups were weaned at 21 days of age and were maintained under controlled conditions of light (14 h light:10 h darkness), temperature $\left(22^{\circ} \mathrm{C}\right)$ and humidity, with free access to food and water. Animals were handled according to the Guiding Principles for the Care and Use of Research Animals approved by the Animal Care and Use Committee of the Centro de Estudios Farmacológicos y Botánicos (CEFYBO-CONICET) School of Medicine (UBA).

\section{In vivo studies}

At 26-28 days of age, female rats were i.p. injected with 10 IU eCG (in $0.10 \mathrm{ml}$ saline) to induce the growth of the first generation of pre-ovulatory follicles. After $48 \mathrm{~h}$, the animals were i.p. injected with $10 \mathrm{IU}$ hCG (in $0.10 \mathrm{ml}$ saline) to induce ovulation, which usually occurs within $12 \mathrm{~h}$ after hCG administration in this rat colony. Simultaneously, some animals were injected with vehicle.

Experiment 1 To study the expression of Ob-R, eight to ten animals were killed by decapitation at different times during the gonadotropin or vehicle treatment. The medial basal hypothalamus $(\mathrm{MBH})$, the anterior pituitary and both the ovaries were immediately dissected out, frozen on dry ice and stored at $-72{ }^{\circ} \mathrm{C}$. The $\mathrm{MBH}$ tissue fragment was bounded rostrally by the posterior border of the optic chiasma, laterally by the lateral sulcus and caudally by the mammillary bodies and cut to a depth of $\sim 2 \mathrm{~mm}$.

Experiment 2 To study the effect of different levels of leptin on the expression of its receptors during the ovulatory process, rats received one of the two following treatments: 1) acute treatment (Ricci et al. 2006), in which the rats received five i.p. injections of either recombinant rat leptin
(5 $\mu \mathrm{g} / 0 \cdot 15 \mathrm{ml}$ PBS-BSA) or PBS-BSA alone (control) $1 \mathrm{~h}$ before hCG administration and at intervals of $150 \mathrm{~min}$ until killing and 2) chronic treatment (Roman et al. 2005), at 22 days of age, in which the rats received an i.p. injection of either recombinant rat leptin $(3 \mu \mathrm{g} / 0 \cdot 15 \mathrm{ml}$ PBS-BSA) or PBS-BSA alone (control) per day until the day the animals were killed. Both leptin and PBS-BSA were administered at the beginning of the light period to avoid the influence of this protein on daily feeding. Body weight and food intake were monitored daily. At 28 days of age, animals received the same gonadotropin treatment as before. The rats from these two leptin treatments (10-12 per group) were killed $10 \mathrm{~h}$ after the hCG injection by decapitation, since this is a pre-ovulatory moment when all factors involved in ovulation are at their highest levels (Faletti et al. 1999a). The MBH, the anterior pituitary and both the ovaries were immediately dissected out, frozen on dry ice and stored at $-72{ }^{\circ} \mathrm{C}$ until the measurement of the expression of leptin receptors by western blot analysis.

\section{In vitro studies}

Tissue culture After $4 \mathrm{~h}$ of gonadotropin treatment, animals were killed by decapitation. The $\mathrm{MBH}$, the anterior pituitary and both the ovaries were immediately removed and placed in different plates containing Dulbecco's modified Eagle's medium (DMEM)/F12 (1:1) medium (Bio-Rad Laboratories) with $25 \mathrm{mM}$ HEPES, $100 \mathrm{U} / \mathrm{ml}$ penicillin, $100 \mu \mathrm{g} / \mathrm{ml}$ streptomycin, $0.5 \mu \mathrm{g} / \mathrm{ml}$ fungizone and $2 \mathrm{mM} \mathrm{L}$-glutamine. Each hypothalamus or anterior pituitary was placed individually in a final volume of $300 \mu \mathrm{l} /$ well culture medium at $37^{\circ} \mathrm{C}$ under a humidified atmosphere $\left(5 \% \mathrm{CO}_{2}: 95 \% \mathrm{O}_{2}\right)$. After 30-min pre-incubation, the medium was replaced by fresh medium in either the presence or the absence of leptin $(0 \cdot 3-500 \mathrm{ng} / \mathrm{ml})$ and incubated for 2 or $3 \mathrm{~h}$ for hypothalamus (Lebrethon et al. 2000) or pituitary (Fernandez-Fernandez et al. 2005) respectively. Ovaries were dissected free offat and bursa and cut into pieces of approximately equal size (four slices per ovary). Ovarian slices (four slices/well) were placed in a final volume of $500 \mu \mathrm{l} /$ well culture medium at $37^{\circ} \mathrm{C}$ in a humidified atmosphere $\left(5 \% \mathrm{CO}_{2}: 95 \% \mathrm{O}_{2}\right)$. After 30 -min pre-incubation, the medium was replaced by either fresh medium alone or medium containing different leptin concentrations $(0 \cdot 3-500 \mathrm{ng} / \mathrm{ml})$ and incubated for $4 \mathrm{~h}$ (Ricci et al. 2006). The leptin doses used in these studies were obtained from previous reports (Spicer \& Francisco 1997, Ricci et al. 2006).

After the respective incubation periods, all tissues were recovered and frozen on dry ice and stored at $-72{ }^{\circ} \mathrm{C}$ to measure the expression of leptin receptors by western blot analysis. The medium samples from hypothalamic explants were boiled to inactivate endogenous protease activity and stored at $-20{ }^{\circ} \mathrm{C}$ as the other culture media, until assayed for hormone content. At least three independent experiments were run for each culture condition using different tissue preparations. 


\section{Drugs and chemicals}

hCG, recombinant rat leptin and protease inhibitors were purchased from Sigma-Aldrich. eCG was obtained from Syntex SA (Buenos Aires, Argentina). [1, 2, 6, 7- $\left.{ }^{3} \mathrm{H}\right]$ progesterone and $\left[2,4,6,7-{ }^{3} \mathrm{H}\right] 17 \beta$-oestradiol were obtained from Amersham Pharmacia Biotech. The western blotting reagents were obtained from Sigma-Aldrich and Bio-Rad Laboratories.

\section{Western blot analysis}

Soluble tissue extracts were prepared as previously described (Ricci et al. 2006). Briefly, hypothalamus, anterior pituitary or ovarian tissues were homogenized in $20 \mathrm{mM}$ ice-cold Tris- $\mathrm{HCl}$ buffer $(\mathrm{pH} 7 \cdot 4)$ containing $0.25 \mathrm{mM}$ sucrose, $1 \mathrm{mM}$ EDTA, $10 \mu \mathrm{g} / \mathrm{ml}$ aprotinin, $10 \mu \mathrm{g} / \mathrm{ml}$ leupeptin, $100 \mu \mathrm{g} / \mathrm{ml}$ phenylmethylsulphonyl fluoride and $10 \mu \mathrm{g} / \mathrm{ml}$ trypsin inhibitors. The homogenates were centrifuged at $7800 \mathrm{~g}$ at $4{ }^{\circ} \mathrm{C}$ for $15 \mathrm{~min}$ and the protein concentration in the supernatant was determined by the Bradford method with BSA as the standard. Homogenates were boiled for $5 \mathrm{~min}$ in buffer containing $0 \cdot 3 \%(\mathrm{w} / \mathrm{v})$ bromophenol blue and $1 \%(\mathrm{v} / \mathrm{v}) \quad \beta$-mercaptoethanol. Equal amounts of protein $(100 \mu \mathrm{g})$ were loaded onto $4 \%(\mathrm{w} / \mathrm{v})$ $0 \cdot 125 \mathrm{M}$ Tris- $\mathrm{HCl}(\mathrm{pH} 6 \cdot 8)$ stacking polyacrylamide gel, followed by a $7 \cdot 5 \%(\mathrm{w} / \mathrm{v}) \quad 0.375 \mathrm{M}$ Tris- $\mathrm{HCl}(\mathrm{pH} 8 \cdot 8)$ separating polyacrylamide gel. Following electrophoresis, proteins were transferred to polyvinylidene difluoride membrane (Bio-Rad Laboratories) for $60 \mathrm{~min}$ in a cold chamber using a Bio-Rad transblot apparatus. Membranes were first blocked at $4{ }^{\circ} \mathrm{C}$ overnight in Tris- $\mathrm{HCl}$ :saline $(50 \mathrm{mM}$ Tris$\mathrm{HCl}: 150 \mathrm{mM} \mathrm{NaCl}, \mathrm{pH} \mathrm{7.5)}$ containing 5\% (w/v) of milk powder, and then incubated at $4{ }^{\circ} \mathrm{C}$ overnight with antibody raised in rabbit against Ob-R (H-300; Santa Cruz Biotechnology, Santa Cruz, CA, USA). The final dilution of antibody was 1:200. The membranes were washed four times for $15 \mathrm{~min}$ each in Tris-HCl:saline containing $0 \cdot 1 \%(\mathrm{v} / \mathrm{v})$ Tween20 ( $\mathrm{pH} 7 \cdot 5 ;$ TTBS). Then, the sections were incubated for $1 \mathrm{~h}$ at room temperature with goat anti-rabbit $\operatorname{IgG}(1: 2500)$ as the secondary antibody (Santa Cruz Biotechnology). The antibody was then washed off in TTBS and the immunoreactive bands were visualized using chemiluminescence detection reagents (Sigma-Aldrich) and exposed to Kodak X-OMAT film. Negative controls were carried out by omitting the incubation with the primary antibody and no bands were detected. Positive controls were carried out using the extract of different rat tissues like brain and placenta. Before reuse, the membranes were stripped, blocked and reprobed according to the manufacturer's instructions. The membranes were reprobed with anti-actin antibody (A2066, Sigma-Aldrich of Argentina SA). Molecular weight standards (Kaleidoscope St, Bio-Rad Laboratories) were run under the same conditions to identify the protein bands. Blots were scanned using a scanning UMAX Astra 12205 and densitometry was analyzed using a Dekmate III Sigma Gel software package (Jandel Scientific software). The data were normalized to $\beta$-actin protein levels in each sample to avoid procedural variability.

\section{Immunohistochemistry}

Immunostaining of $\mathrm{Ob}-\mathrm{R}$ in ovarian tissue from culture studies was performed as previously (Archanco et al. 2003). Ovarian tissues were fixed in neutral buffered formalin, embedded in paraffin and sliced in $6 \mu \mathrm{m}$ thick sections. Then, the slices were deparaffinized with xylene and rehydrated with graded ethanol. Endogenous peroxidase activity was blocked by incubation in $0.5 \%(\mathrm{v} / \mathrm{v})$ hydrogen peroxide (30\%) in absolute methanol at room temperature for $30 \mathrm{~min}$. Background blocking was performed incubating with $10 \%$ (v/v) normal goat serum (Sigma-Aldrich) for $1 \mathrm{~h}$ at room temperature, before incubation with the specific antiserum. The tissue sections were incubated overnight at $4{ }^{\circ} \mathrm{C}$ with $\mathrm{Ob}-\mathrm{R}$ mouse monoclonal antibody (Santa Cruz Biotechnology) raised in mouse against Ob-R (B-3) diluted 1:50, as primary antibody. The detection system used was the peroxidase anti-peroxidase method (PAP). The sections were incubated with goat anti-mouse secondary antibody (Sigma-Aldrich; 1:50 dilution) at room temperature for $1 \mathrm{~h}$ and mouse PAP (Sigma-Aldrich; 1:100 dilution) at room temperature for $1 \mathrm{~h}$. All antibodies were diluted in PBS containing $0 \cdot 2 \%(\mathrm{v} / \mathrm{v})$ Triton X-100. Colour development was performed with a solution containing $0.06 \%(\mathrm{w} / \mathrm{v})$ 3,3'-diaminobenzidine (Sigma-Aldrich) plus $0 \cdot 01 \%(\mathrm{v} / \mathrm{v})$ hydrogen peroxide for 15-30 min. Control sections were performed by omitting the primary antibody. Finally, the sections were dehydrated, mounted with Entellan New (Merck) and observed with a Zeiss Axiophot light microscope.

\section{Hormone assays}

Progesterone and $17 \beta$-oestradiol were quantified by RIA in the ovarian culture medium as described previously (Roman et al. 2005, Ricci et al. 2006). Antisera were kindly provided by Dr G D Niswender (Colorado State University, Fort Collins, CO, USA). The sensitivity of both assays was $15 \mathrm{pg} / \mathrm{ml}$. The cross-reactivities for oestradiol antiserum were $1 \%$ for progesterone and testosterone, $5 \%$ for oestriol and $10 \%$ for oestrone. The cross-reactivities for progesterone antiserum were $<2.0 \%$ for $20 \alpha$-dihydro-progesterone and deoxycorticosterone and $1.0 \%$ for other steroids in the serum. Results were expressed as $\mathrm{ng} / \mathrm{mg}$ protein.

Luteinizing hormone (LH)-releasing hormone (LHRH) was measured by RIA in the hypothalamic culture medium as described previously (Faletti et al. 1999b). The highly specific LHRH antiserum was kindly provided by Ayala Barnea (University of Texas Southwestern Medical Center, Dallas, TX, USA). The sensitivity of the assay was $0 \cdot 2$ pg per tube and the curve was linear up to $100 \mathrm{pg}$ LHRH. The intra-assay coefficient of variation of the LHRH RIA ranged from 4 to $7 \cdot 3 \%$, and the inter-assay coefficient of variation was $8 \cdot 9 \%$. LH was measured by RIA in the pituitary culture medium using a double antibody and reagents kindly provided by the NIAMDD Rat Pituitary Programme. The sensitivity of the assay was $4 \mathrm{pg}$ per tube and the curve was linear up to $1000 \mathrm{pg}$ LH. The intra- and interassay coefficients of variation were 8 and $10 \%$ respectively. 
LHRH and LH for iodination were purchased from Peninsula Laboratories. Iodine-125 for iodination was purchased from New England Nuclear. All samples were measured in duplicate. The results were expressed as pg per hypothalamus or pituitary.

\section{Statistical analysis}

All data are expressed as means \pm s.E.M. Comparisons between groups were performed using a two-way ANOVA with Bonferroni post-tests for the in vivo experiments, and one-way ANOVA with Dunnett's multiple comparison test between each concentration and controls for the in vitro experiments. The difference between the leptin-treated group and the buffer group in the in vivo treatment with leptin was analysed using Student's $t$-test. Differences between groups were considered significant when $P<0 \cdot 05$.

\section{Results}

Effect of the gonadotropin treatment on the expression of leptin receptors

The expression of leptin receptors was evaluated at different times after the eCG/hCG or vehicle treatment by western blot analysis in the HPO axis. All these tissues revealed both the presence of long and short receptor isoforms by a polyclonal antibody raised against a recombinant protein corresponding to amino acids 541-840 mapping a region within an internal domain of $\mathrm{Ob}-\mathrm{R}$. Ob-R-immunoreactive proteins with apparent relative molecular masses of 210,150 and $110 \mathrm{kDa}$ were detected, as previously described with $\mathrm{CHO}$ cells (Matsuda et al. 1999), hypothalamus tissue (Pal \& Sahu 2003), adipose tissue (Meli et al. 2004) and ovarian tissue (Ricci et al. 2006). Protein bands at 150 and $110 \mathrm{kDa}$ were consistent with the predicted size of $\mathrm{Ob}-\mathrm{Rb}$ and the short isoforms $(\mathrm{Ob}-\mathrm{Rs})$ respectively based on amino acid composition. Thus, these two bands were considered to be leptin receptors. Figures 1 and 2 show the results of leptin receptor expression in the different tissues assayed during the gonadotropin treatment. No differences were found in the expression of leptin receptor protein in the rats treated with vehicle. eCG induced an increase in the expression of both hypothalamic Ob-R proteins at 24-h post-treatment when compared with that obtained from animals without treatment $(-48 \mathrm{~h})$. These increases represented $73 \cdot 7 \%$ $(P<0.05)$ and $73.5 \%(P<0.01)$ for $\mathrm{Ob}-\mathrm{Rb}$ and $\mathrm{Ob}-\mathrm{Rs}$ respectively (Fig. 1B and C). Furthermore, these levels were significantly higher than those obtained from animals treated with vehicle $(P<0.05$ and $P<0.01$ for long and short proteins respectively). After $48 \mathrm{~h}$ of eCG treatment, the expression returned to values similar to those obtained without treatment and the hCG injection did not alter these levels.

Results obtained for the expression of the levels of pituitary and ovarian leptin receptor are shown in Fig. 2 (left and right panels respectively). eCG treatment produced an increase in the levels of the pituitary $\mathrm{Ob}-\mathrm{Rb}$ expression at $24 \mathrm{~h}(79 \cdot 7 \%$;
A
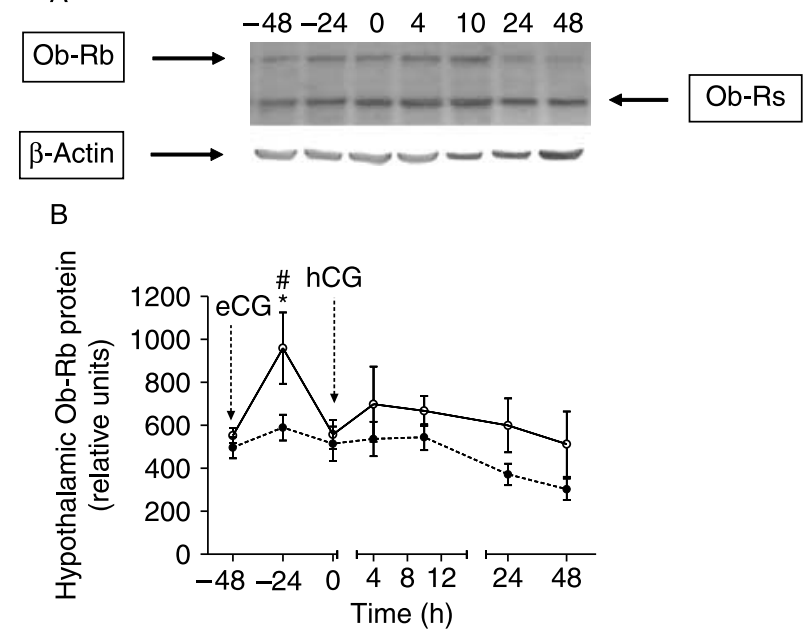

C

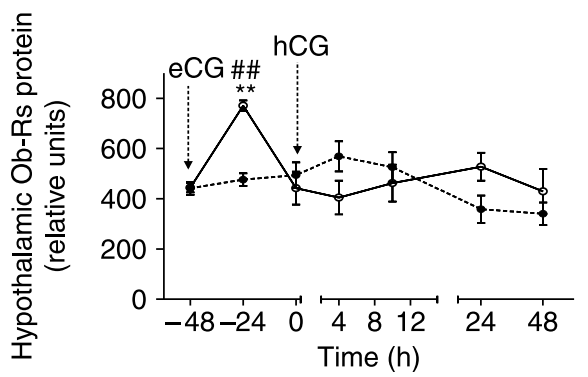

Figure 1 Pattern of changes in protein levels of the long (Ob-Rb) and short (Ob-Rs) isoforms of leptin receptor in the hypothalamic tissue obtained at different times from immature rats primed with eCG/hCG (-O-) or vehicle (- - - -). (A) Expression of both Ob-R and $\beta$-actin, as protein control, by western blot analysis, from rats primed with eCG/hCG. (B and C) Quantitative analysis of immunoreactive bands for Ob-Rb (B) and Ob-Rs (C). Data points represent the mean \pm S.E.M. for four to five samples per group. Each sample represents two hypothalami from different animals at the same time. ${ }^{*} P<0 \cdot 05,{ }^{* *} P<0 \cdot 01$ vs $-48 \mathrm{~h} .{ }^{\sharp} P<0 \cdot 05,{ }^{\sharp \#} P<0 \cdot 01$ versus vehicle (two-way ANOVA and Bonferroni post-tests).

$P<0 \cdot 01)$ and at $48 \mathrm{~h}(98.3 \% ; P<0 \cdot 01)$ post-injection in comparison with that obtained from animals without treatment $(-48$ h; Fig. 2B). Furthermore, these levels were significantly higher than those obtained from animals treated with vehicle $(P<0.05$ at $48-\mathrm{h}$ post-eCG). These values remained high after hCG injection and decreased after ovulation (Fig. 2B). Similar results were obtained with the expression of the pituitary Ob-Rs protein, in which the increase was $184 \%$ at $24 \mathrm{~h}(P<0 \cdot 05)$ and $198 \%$ at $48 \mathrm{~h}(P<0 \cdot 01)$ post-eCG in comparison with that obtained from animals without treatment ( -48 h; Fig. 2C).

The expression of both isoforms of leptin receptor in the ovarian tissue obtained from rats treated with $\mathrm{eCG} / \mathrm{hCG}$ is shown in Fig. 2 (right panel). The administration of eCG induced an increase in the expression of $\mathrm{Ob}-\mathrm{Rb}$ proteins at $24 \mathrm{~h}(49 \cdot 9 \%$; $P<0.05)$ and at $48 \mathrm{~h}(71.2 \% ; P<0.01)$ post-injection in comparison with that obtained from animals without treatment $(-48 \mathrm{~h})$. After hCG administration, the expression of this protein 


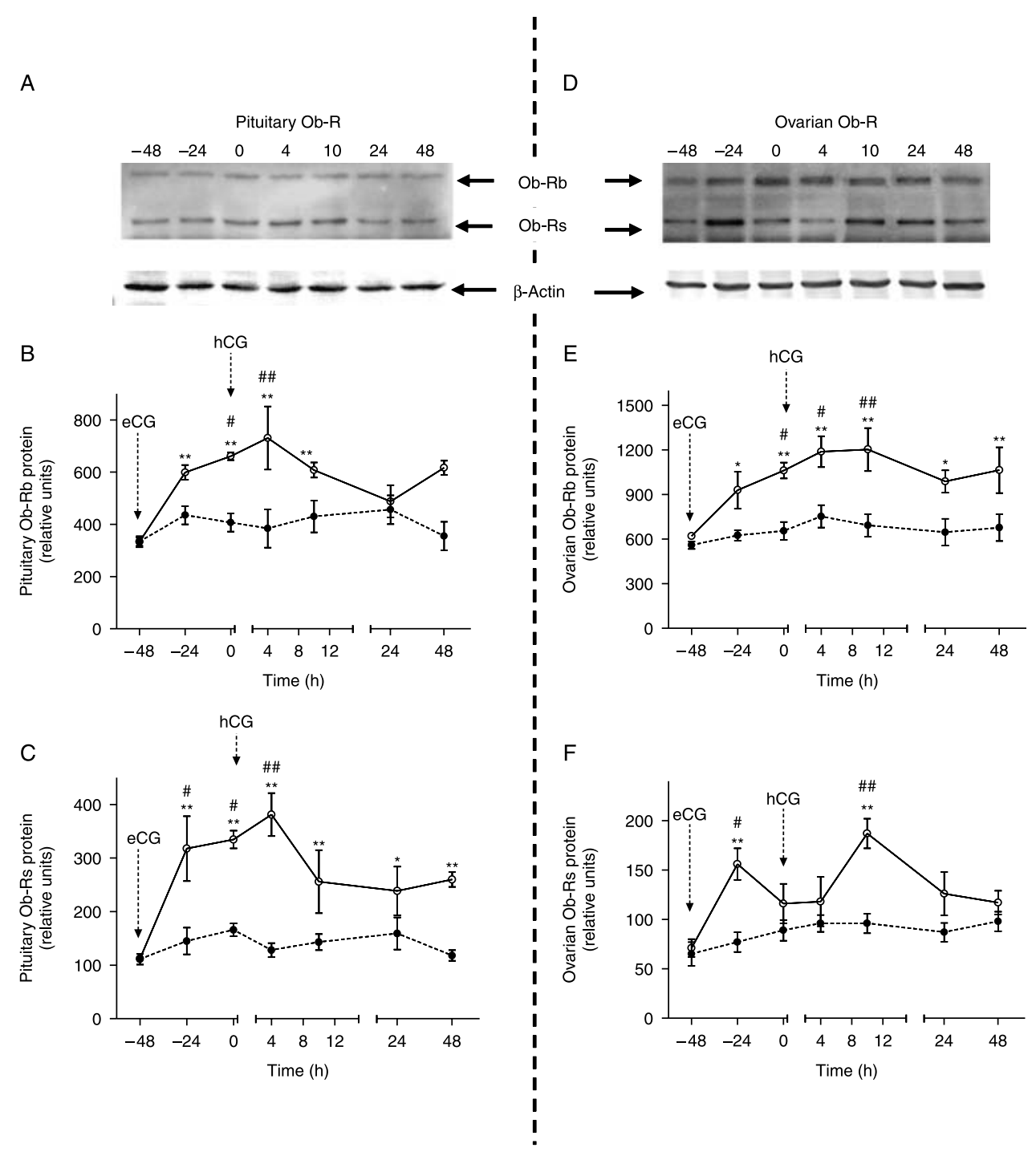

Figure 2 Pattern of changes in protein levels of the long $(\mathrm{Ob}-\mathrm{Rb})$ and short (Ob-Rs) isoforms of leptin receptor in the pituitary (left panel) and ovarian (right panel) tissue obtained at different times from immature rats primed with eCG/hCG (-O—) or vehicle (- - - ). (A and D) Expression of both Ob-R isoforms and $\beta$-actin, as protein control, by western blot analysis, from rats primed with eCG/hCG. (B and C) Quantitative analysis of immunoreactive bands for $\mathrm{Ob}-\mathrm{Rb}(\mathrm{B})$ and $\mathrm{Ob}-\mathrm{Rs}(\mathrm{C})$ in pituitary tissue (left panel). (E and F) Quantitative analysis of immunoreactive bands for Ob-Rb (E) and Ob-Rs (F) in ovarian tissue (right panel). Data points represent the mean \pm S.E.M. for four to seven samples per group. Each sample represents two pituitary or two to four ovaries from different animals at the same time. ${ }^{*} P<0 \cdot 05,{ }^{* *} P<0 \cdot 01 \mathrm{vs}-48 \mathrm{~h} .{ }^{\sharp} P<0 \cdot 05,{ }^{\sharp} P<0 \cdot 01$ versus vehicle (two-way ANOVA and Bonferroni post-tests).

remained high and reached a maximum at $10-\mathrm{h}$ post-injection $(P<0 \cdot 01)$. These levels were significantly higher than those obtained from animals treated with vehicle $(P<0 \cdot 05$ at 0 and $4 \mathrm{~h}$, and $P<0 \cdot 01$ at $10-\mathrm{h}$ post-hCG; Fig. 2E). In the case of the ovarian $\mathrm{Ob}-\mathrm{Rs}$, eCG induced an increase in their expression at 24-h post-treatment $(119 \cdot 7 \% ; P<0 \cdot 01)$ when compared with that obtained from animals without treatment $(-48 \mathrm{~h})$. In addition, these levels were significantly higher than those obtained from animals treated with vehicle $(P<0 \cdot 05)$. After $48 \mathrm{~h}$ of eCG treatment, the expression returned to values similar to those obtained from rats treated with vehicle. hCG induced an increase at $10-\mathrm{h}$ post-administration $(P<0 \cdot 01)$ and after ovulation, no differences were found in the expression of $\mathrm{Ob}-\mathrm{Rs}$ between rats primed with eCG/hCG and those injected with vehicle.

\section{Effect of different levels of leptin on the expression of leptin receptors}

In vivo studies Figure 3 shows the results obtained with the ovarian tissue from immature rats subjected to both the 
A

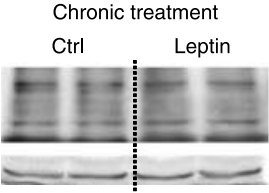

B
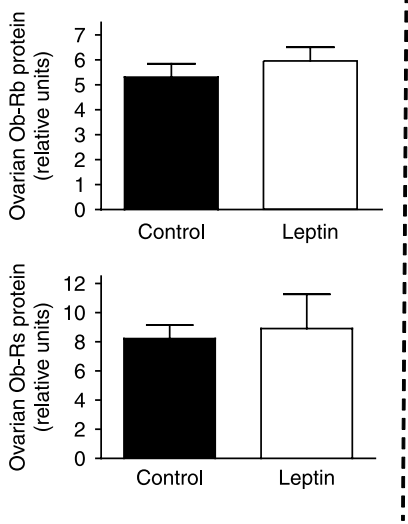

Figure 3 Effect of chronic (left panel) and acute (right panel) treatment of leptin on the expression of ovarian leptin receptors. In the chronic treatment, immature rats were daily injected with either PBS-BSA or $3 \mu \mathrm{g}$ leptin. After a week, the animals were primed with eCG/hCG. In the acute treatment, immature rats were primed with either eCG/hCG and treated with PBS-BSA or $5 \mu \mathrm{g}$ leptin at $1 \mathrm{~h}$ before hCG and at 150-min intervals. All the animals were killed $10 \mathrm{~h}$ after hCG administration. (A) Expression of both ovarian Ob-R isoforms and $\beta$-actin, by western blot analysis. (B) Quantitative analysis of immunoreactive bands for both $\mathrm{Ob}-\mathrm{R}$ in ovarian tissue. Data points represent the mean \pm s.E.M. for four to five samples per group. Each sample represents two ovaries from different animals with the same treatment. ${ }^{*} P<0 \cdot 05$ versus control (Student's $t$-test).

chronic and acute treatments. No differences were found in the expression of leptin receptors of either $\mathrm{Ob}-\mathrm{Rb}$ or $\mathrm{Ob}-\mathrm{Rs}$ in ovaries between animals treated with a daily dose of leptin and control animals (left panel). The same results were found with hypothalamic and pituitary tissue (data not shown). By contrast, the acute treatment with leptin significantly increased the expression of both leptin receptor isoforms $(P<0 \cdot 05)$ in ovarian tissue (Fig. 3, right panel), but no differences were found in either hypothalamic or pituitary tissue (data not shown).

In vitro studies Figures 4 and 5 show the expression of the leptin receptors in the hypothalamic, pituitary and ovarian tissues after incubation for 2,3 or $4 \mathrm{~h}$ respectively, in the presence or absence of different levels of leptin $(0 \cdot 3-500 \mathrm{ng} / \mathrm{ml})$. In the case of hypothalamus, the results show a biphasic effect of leptin on the expression of its receptors (Fig. 4). The addition of low concentrations of leptin $(0.3 \mathrm{ng} / \mathrm{ml})$ significantly reduced $(-42 \%, P<0 \cdot 01)$ while high concentrations ( 30 and $300 \mathrm{ng} / \mathrm{ml}$ ) increased the protein content of the $\mathrm{Ob}-\mathrm{Rb}$ isoform $(52$ and $62 \%$
A

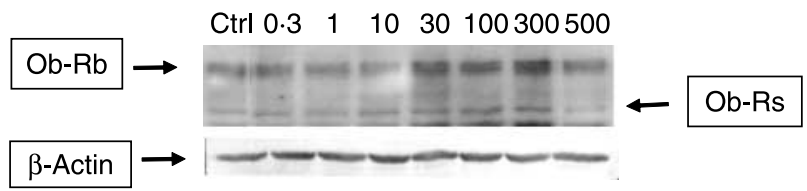

B

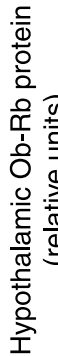
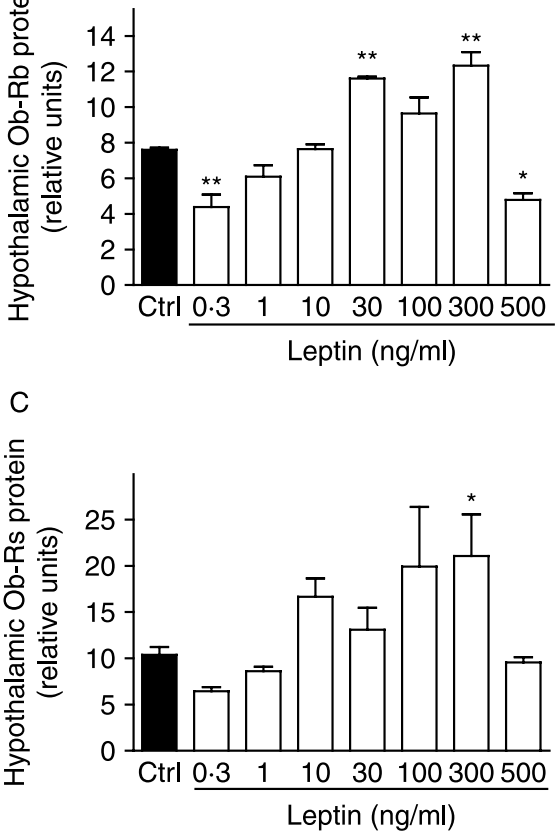

Figure 4 In vitro effect of leptin on the protein levels of hypothalamic long $(\mathrm{Ob}-\mathrm{Rb})$ and short (Ob-Rs) isoforms. Hypothalamic explants were obtained $4 \mathrm{~h}$ after $\mathrm{hCG}$ administration from immature rats primed with eCG/hCG and incubated for $2 \mathrm{~h}$ either in the presence or in the absence of different concentrations of leptin (30-500 ng/ml). (A) Expression of both Ob-R and $\beta$-actin, as protein control, by western blot analysis. (B and C) Quantitative analysis of immunoreactive bands for $\mathrm{Ob}-\mathrm{Rb}(\mathrm{B})$ and $\mathrm{Ob}-\mathrm{Rs}(\mathrm{C})$. Results are mean \pm s.E.M. of three independent experiments; each treatment was applied in quadruplicate culture well and each sample represents two hypothalami from different animals exposed at the same concentration $(n=6) . * P<0 \cdot 05, * * P<0 \cdot 01$ versus control (one-way ANOVA and Dunnett's multiple comparison test).

respectively; $P<0 \cdot 01)$ when compared with controls, although the highest concentrations assayed produced a significant reduction $(P<0 \cdot 05$; Fig. 4B). The content of hypothalamic $\mathrm{Ob}-\mathrm{R}$ s protein showed the same pattern as that obtained with the long isoform, although the results were significant only at $300 \mathrm{ng} / \mathrm{ml}$, when a densitometric analysis was performed (Fig. 4C).

In the case of pituitary tissue (Fig. 5, left panel), the expression of $\mathrm{Ob}-\mathrm{Rb}$ protein was significantly increased at leptin concentrations of $10 \mathrm{ng} / \mathrm{ml}(74 \%, P<0 \cdot 01$; Fig. 5B), while $\mathrm{Ob}-\mathrm{Rs}$ isoforms reached a maximum at $30 \mathrm{ng} / \mathrm{ml}$ (130\%, $P<0 \cdot 01$; Fig. 5C), both when compared with those obtained from controls. When ovarian tissues were incubated 
A
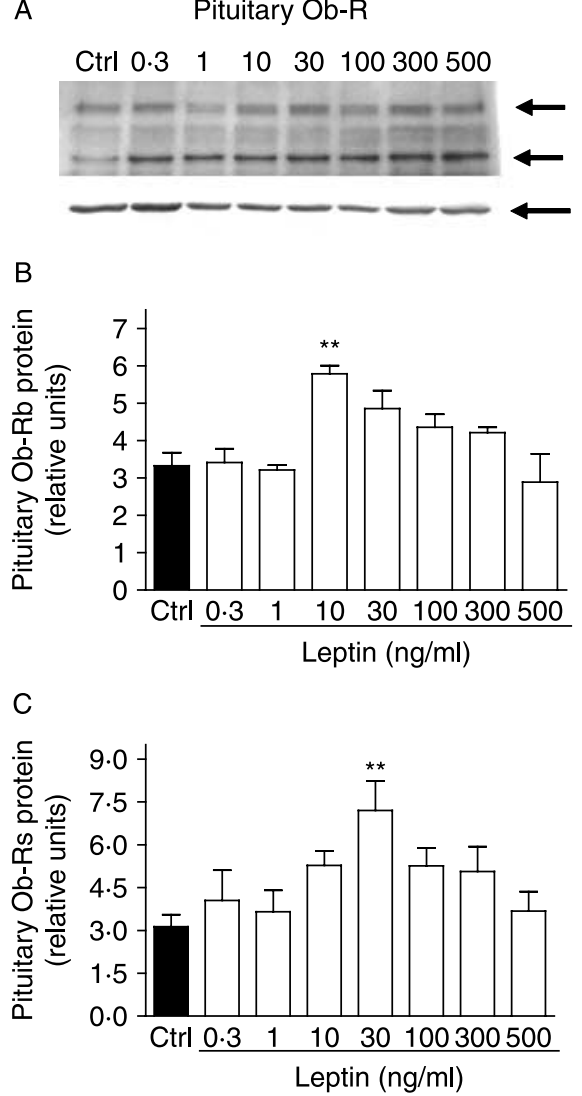

\section{Ovarian Ob-R}

Ctrl $0.3 \quad 1 \quad 10 \quad 30100300500$
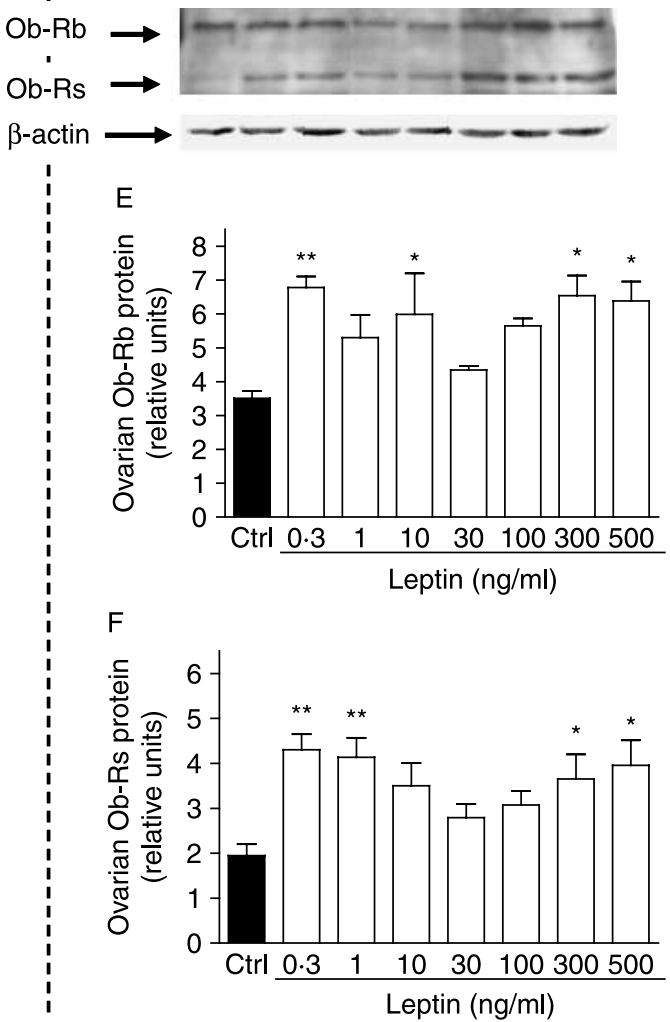

Figure 5 In vitro effect of leptin on the protein levels of pituitary (left panel) and ovarian (right panel) of both the long $(\mathrm{Ob}-\mathrm{Rb})$ and short (Ob-Rs) isoforms. Pituitary and ovarian explants were obtained $4 \mathrm{~h}$ after hCG administration from immature rats primed with eCG/hCG and incubated for 3 or $4 \mathrm{~h}$ respectively either in the presence or in the absence of different concentrations of leptin $(0 \cdot 3-500 \mathrm{ng} / \mathrm{ml}$ ). (A and D) Expression of both Ob-R and $\beta$-actin, as protein control, by western blot analysis. (B and C) Quantitative analysis of immunoreactive bands for $\mathrm{Ob}-\mathrm{Rb}(\mathrm{B})$ and $\mathrm{Ob}-\mathrm{Rs}(\mathrm{C})$ in pituitary tissue (left panel). (E and F) Quantitative analysis of immunoreactive bands for Ob-Rb (E) and Ob-Rs (F) in the ovarian tissue (right panel). Results are mean \pm S.E.M. of three independent experiments; each treatment was applied in quadruplicate culture well and each sample represents two pituitary or two ovaries from different animals exposed at the same concentration $(n=6) .{ }^{*} P<0 \cdot 05,{ }^{* *} P<0 \cdot 01$ versus control (one-way ANOVA and Dunnett's multiple comparison test).

in the presence of different concentrations of leptin, the expression of both isoforms of leptin receptors significantly increased in different ranges of leptin levels: at $0 \cdot 3,10,300$ and $500 \mathrm{ng} / \mathrm{ml}$ for $\mathrm{Ob}-\mathrm{Rb}$ and at $0 \cdot 3,1,300$ and $500 \mathrm{ng} / \mathrm{ml}$ for Ob-Rs (Fig. 5, right panel). These increases oscillated between 70 and $90 \%$ as compared with controls.

In order to study the effect of leptin on these tissues and relate it with the changes obtained in the expression of leptin receptors, the secretion of $\mathrm{LHRH}$ was measured in hypothalamic incubation medium, $\mathrm{LH}$ in pituitary incubation medium, and progesterone and $17 \beta$-oestradiol were measured in the ovarian incubation medium. These data are summarized in Table 1. The addition of leptin led to an increase in LHRH secretion to reach a maximum at $1 \mathrm{ng} / \mathrm{ml}$ compared with those obtained from controls, while higher concentrations did not alter this secretion. Leptin also induced an increase in LH release from pituitary cultures when compared with that obtained from controls, but it was significant at $30 \mathrm{ng} / \mathrm{ml}$. In the ovarian culture, the presence of leptin produced a dose-dependent biphasic effect on the production of progesterone. Progesterone concentration was significantly increased at $1-10 \mathrm{ng} / \mathrm{ml}$ and significantly reduced at $300 \mathrm{ng} / \mathrm{ml}$ when compared with controls. No differences were found in $17 \beta$-oestradiol concentrations (Table 1).

In order to confirm the results obtained with the in vitro assays, and to localize $\mathrm{Ob}-\mathrm{R}$ in ovarian tissue, immunolocalization was assessed. The whole ovarian tissue was incubated in the same conditions as those in the ovarian tissue culture in the presence or absence of some leptin concentrations that showed an increase in the content of $\mathrm{Ob}-\mathrm{R}$ protein. Figure 6 shows the $\mathrm{Ob}-\mathrm{R}$ immunostaining obtained. As expected, the $\mathrm{Ob}-\mathrm{R}$ receptors were detected mainly in granulosa and 
Table 1 In vitro effect of different leptin levels on the production of luteinizing hormone (LH)-releasing hormone (LHRH), LH, progesterone and $17 \beta$-oestradiol by cultures of tissue explants, from immature gonadotropins-primed rats. Hypothalamic, pituitary and ovarian explants were obtained $4 \mathrm{~h}$ after hCG administration from immature rats primed with eCG/hCG and incubated for 2,3 or $4 \mathrm{~h}$ respectively either in the presence or in the absence of different concentrations of leptin $(0 \cdot 3-500 \mathrm{ng} / \mathrm{ml})$. Values are expressed as means \pm s.E.M. of three independent experiments; each treatment was applied in quadruplicate culture well and each sample represents the concentrations of the hormone in the culture medium of one hypothalamus, one pituitary or two ovaries from different animals exposed at the same concentration $(n=8-12)$

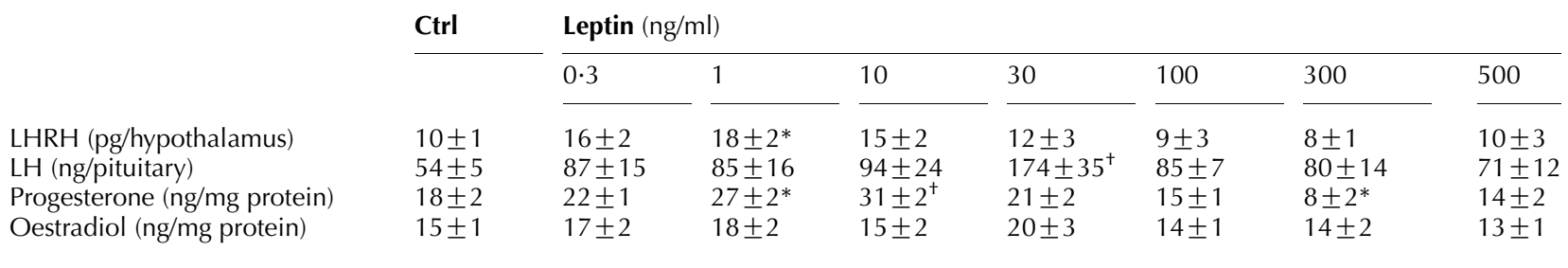

${ }^{*} P<0 \cdot 05,{ }^{+} P<0 \cdot 01$ versus control (one-way ANOVA and Dunnett's multiple comparison test).

cumulus oophorus cells. Weaker immunostaining was observed in oocytes, theca and interstitial cells (Fig. 6A). A stronger immunostaining was observed in ovarian tissue incubated with low concentrations $(0.3 \mathrm{ng} / \mathrm{ml})$ of leptin (Fig. 6C) compared with control (Fig. 6B). Similar results were obtained when ovarian tissues were incubated with high concentrations $(300 \mathrm{ng} / \mathrm{ml})$ of leptin (Fig. 6F and $\mathrm{G}$ ). Figure 6D, E, H and I show the negative controls from each sample.

\section{Discussion}

The reproductive function is regulated by a close relationship between the hypothalamus, the pituitary and the gonads, which form the reproductive axis. This axis is, in turn, modulated by multiple and complex metabolic and nutritional factors. Although there are a lot of experimental evidence about the mechanism involved in regulating the reproductive function, the complete system remains poorly understood. The discovery of leptin, a $16 \mathrm{kDa}$ protein synthesized primarily by adipose tissue, opened up a new perspective in the complex endocrine system that controls the reproductive system. Since $\mathrm{mRNA}$ for leptin receptor has been detected in ovarian tissue, many studies have demonstrated that leptin may have direct effects on the ovarian function. However, most of these studies are contradictory, since both stimulatory and inhibitory actions on the ovarian function have been described (Ahima et al. 1997, Zachow \& Magoffin 1997, Clément et al. 1998, Strobel et al. 1998, Agarwal et al. 1999, Barkan et al. 1999, 2005, Brannian et al. 1999, Zachow et al. 1999, Duggal et al. 2000, 2002a, Almog et al. 2001). Recently, we have demonstrated that leptin may be regulating the ovulatory process, as when the levels of this protein are low there is a positive relationship between leptin and the ovarian function (Roman et al. 2005), while when these levels are high, there is a negative relationship between them (Ricci et al. 2006). In this work, we studied the expression of leptin receptors in the rat HPO axis during the ovulatory process and found that gonadotropins regulate these receptors in a differential way. eCG induced an increase in the expression of both the long and short isoforms of leptin receptors in hypothalamus, although this result was only significant with the short forms. Ryan et al. (2003) found that plasmatic leptin decreases $70 \%$ after eCG administration in immature rats primed with eCG/hCG, and that the basal values were recovered 48 -h post-eCG. These results appear to suggest that leptin receptors are sensitive to change in plasmatic leptin concentrations, in order to balance a ligand lack. In a recent study, Meli et al. (2004) observed that the plasmatic leptin concentration was increased in ovariectomized rats in a time-dependent manner. This increase was $50 \%$ in 1 week and $100 \%$ in 22 weeks after ovariectomy. Moreover, the expression of the long isoform decreased in hypothalamus in both 1 and 22 weeks after ovariectomy. These data confirm our findings, since the leptin receptors in the hypothalamus seem to balance the modification of plasmatic leptin levels.

In a previous study, we found that plasmatic leptin levels diminished $4 \mathrm{~h}$ after hCG administration in immature rats primed with eCG/hCG (Ricci et al. 2006). Similar results were found by Ryan et al. (2003) who reported a reduction of $80 \%$ leptin at 9-h post-hCG administration. In our studies, the expression of hypothalamic leptin receptors was not altered by hCG administration, while the content of these receptors was high in both the pituitary and the ovarian tissue. These results suggest that the hypothalamus is not responsive to plasmatic leptin changes during hCG treatment. Ryan et al. (2003) also reported that $\mathrm{mRNA}$ expression of both the short and long forms of the leptin receptor in the immature gonadotropinprimed rat ovary increases after hCG administration, followed by a dramatic reduction $24 \mathrm{~h}$ after this treatment. In the present study, we found that the ovarian content of both proteins $(\mathrm{Ob}-$ $\mathrm{Rb}$ and $\mathrm{Ob}-\mathrm{Rs}$ ) was increased before follicular rupture. In this study, we confirm the results obtained in a previous work with the long isoform (Ricci et al. 2006), where we found that the administration of eCG induced an increase in the expression of $\mathrm{Ob}-\mathrm{R}$ protein, and that hCG administration did not modify this increase. All these data confirm that the production of leptin and its receptors is regulated by gonadotropins 

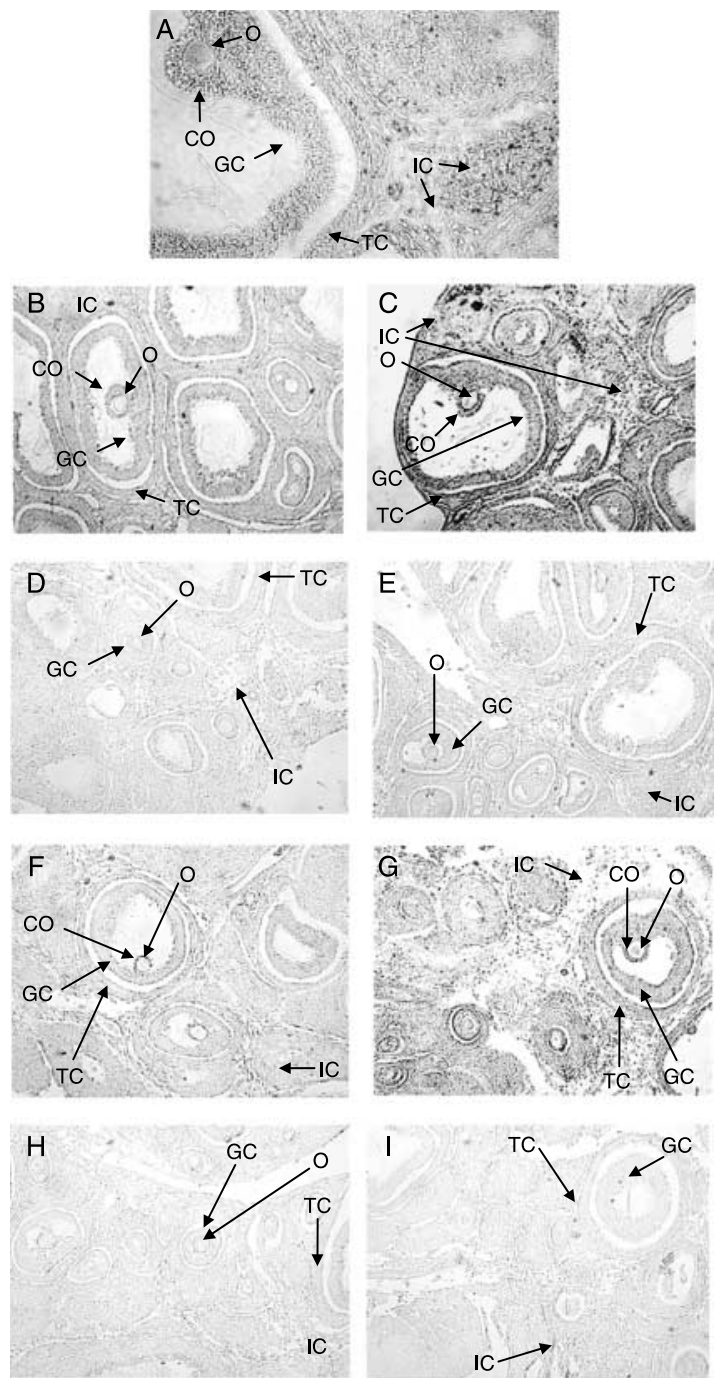

Figure 6 Representative photomicrographs of leptin effect on ovarian Ob-R. Ovarian tissues were obtained $4 \mathrm{~h}$ after hCG administration from immature rats primed with eCG/hCG and incubated for $4 \mathrm{~h}$ either in the presence or in the absence of different concentrations of leptin $(0 \cdot 3$ or $300 \mathrm{ng} / \mathrm{ml})$. (A) Immunostaining from ovarian control without incubation. (B and F) Immunostaining from ovarian control after incubation. ( $D$ and $H$ ) Negative control from $B$ and $F$ respectively. (C) Immunostaining from ovarian tissue exposed at $0.3 \mathrm{ng} / \mathrm{ml}$ leptin. (G) Immunostaining from ovarian tissue exposed at $300 \mathrm{ng} / \mathrm{ml}$. (E and I) Negative control from $\mathrm{C}$ and $\mathrm{G}$ respectively. GC, granulosa cells; CO, cumulus oophorus cells; O, oocyte; IC, interstitial cells. Original magnification: $80 \times$.

in a tissue-dependent manner, indicating their differential targets in different processes, like follicular growth and/or ovulation. The fact that leptin receptors from the pituitary and the ovarian tissues were responsive to hCG is not surprising, because these peripheral tissues are closely involved in the final phase of ovulation and are activated by the hypothalamus-produced gonadotropin-releasing hormones $(\mathrm{GnRH})$, which are in turn, negatively regulated by the ovarian hormones. Since our studies were not able to distinguish the different short isoforms, further studies are necessary to clarify which isoforms are involved in the different events of the ovarian function. However, we firmly believe that these findings will be useful in future investigations, since we have shown for the first time that the expression of leptin receptors along the $\mathrm{HPO}$ axis is clearly modified by gonadotropins in a differential manner.

In previous studies using this biological model, it has been shown that eCG administration resulted in a gradual increase in plasmatic oestrogens, and that after hCG injection, these levels diminished to basal values a few hours before ovulation occurs (Espey et al. 1989, 1991, Ryan et al. 2003). These results, together with those obtained in this work, suggest that oestrogens could be exerting a negative feedback on the expression of leptin receptors in the hypothalamic tissue. These data support the results obtained by Bennett et al. (1998, 1999) who demonstrated that oestrogens modulate the expression of the hypothalamic leptin receptors. On the other hand, it is likely that the expression of leptin receptors in the peripheral tissues is also modulated by steroids, since a positive relationship between steroids and leptin receptors in both the pituitary and ovarian tissue seems to exist. All these data may suggest that leptin receptors in the HPO axis could be differentially regulated by steroids, depending on both the tissue and the gonadotropin treatment timing.

In previous studies, using immature rats primed with $\mathrm{eCG} / \mathrm{hCG}$, we found that an acute treatment with leptin inhibits the ovulatory process (Ricci et al. 2006), whereas a chronic administration with a low dose of this protein enhances it (Roman et al. 2005). Therefore, we investigated whether these treatments were able to modify the expression of leptin receptors. No differences were found in the expression of leptin receptors between animals subjected to the chronic treatment and controls. By contrast, the acute treatment with leptin significantly increased the expression of both the long and short isoforms of leptin receptors in the ovarian tissue, but no differences were found in either the hypothalamic or the pituitary tissue. We initially expected that the changes in the expression of leptin receptors produced by the gonadotropin treatment before ovulation would be altered by leptin administration. However, we found that neither the acute nor the chronic treatments showed significant alterations in their expressions, except for the response with high level of leptin on the ovarian tissue. In a previous study, the chronic administration of leptin for 4 weeks diminished the expression of the mRNA and protein of leptin receptor in the rat hypothalamus (Martin et al. 2000). However, other studies have shown no changes in the expression of leptin receptors after a chronic administration of low doses of leptin for 2 weeks (Pal \& Sahu 2003). Although all these data suggest that both the dose and the timing of leptin administration are critical to obtain either a positive or a negative response, further studies are necessary to clarify this point.

In order to study the effect of a narrow range of leptin concentrations on its receptors, the expression of leptin 
receptors was assessed in hypothalamic, pituitary and ovarian explant cultures either in the presence or in the absence of different leptin levels. We found that leptin differentially regulates its receptors in both dose- and tissue-dependent manner. Again, a similar pattern of responsiveness was obtained with both the long and short isoforms within the same tissue. In the hypothalamic culture, we found that leptin was able to produce a biphasic effect on leptin receptors after a $2-\mathrm{h}$ incubation. The results obtained with low $(0.3 \mathrm{ng} / \mathrm{ml})$ leptin levels suggest again that leptin receptors in hypothalamus are sensitive to changes in the plasmatic leptin concentrations in order to balance modifications of its ligand. It has been reported that leptin levels in the cerebrospinal fluid of normally fed female rats $(0 \cdot 2-0 \cdot 3 \mathrm{ng} / \mathrm{ml})$ are about ten times lower than in the plasma (Grueso et al. 2001, Rocha et al. 2001). The other concentrations of leptin used in this study were, however, higher than those normally found in the cerebrospinal fluid. It was surprising that the hypothalamus was responsive to these levels of leptin. Although we cannot explain this response, we should point out that this is an in vitro system without the presence of numerous regulatory factors, and thus it is difficult to extrapolate. Low concentrations of leptin $(1 \mathrm{ng} / \mathrm{ml})$ were able to induce an increase in LHRH and an inhibition of the content of the leptin receptor, while high concentrations did not alter LHRH secretion and increased the content of leptin receptor when compared with controls. These results are consistent with other previous studies using different biological models. Yu et al. (1997), using hypothalamus explants from adult male rats, demonstrated a significant increase in LHRH only at the lowest concentrations tested $\left(10^{-12}-10^{-10} \mathrm{M}\right)$, whereas they did not find any changes at higher levels. Lebrethon et al. (2000), using hypothalamus explants from pre-pubertal male rats, also reported stimulatory effects on GnRH secretion by the presence of different concentrations of leptin. Watanobe (2002) examined the effects of direct intra-hypothalamic perfusions with leptin $(1-10 \mathrm{ng} / \mathrm{ml})$ on the in vivo release of $\mathrm{GnRH}$ in ovarian steroid-primed ovariectomized rats and found that in normally fed animals, the leptin infusion had no effect, while in 3-day-fasted rats, leptin was effective in stimulating $\mathrm{GnRH}$ secretion.

When we studied the effect of leptin on the peripheral tissues, we observed that the expression of leptin receptors increased in different ranges of leptin levels. The maximal increase in pituitary was at 10 and $30 \mathrm{ng} / \mathrm{ml}$ of leptin for $\mathrm{Ob}-\mathrm{Rb}$ and $\mathrm{Ob}-\mathrm{R}$ s respectively. In turn, we found that $30 \mathrm{ng} / \mathrm{ml}$ of leptin was able to increase significantly the $\mathrm{LH}$ secretion in incubated anterior pituitary. Yu et al. (1997) found that leptin produced a dose-related increase in LH after $3 \mathrm{~h}$ of incubation of hemi-anterior pituitary of adult male rats. This increase reached peaks with $10^{-9} \mathrm{~mol} / \mathrm{l}$. De Biasi et al. (2001) demonstrated that the addition of increasing concentrations of leptin to the incubation medium of proestrus pituitaries produced a dose-related stimulation of $\mathrm{LH}$ release, where the maximal increase was obtained with $10 \mathrm{nmol} / 1$ ( $\sim 16 \mathrm{ng} / \mathrm{ml})$. Leptin also stimulates $\mathrm{LH}$ release by pituitaries from ovariectomized rats, and the treatment with steroid hormones leads to a marked increase in the response (De Biasi et al. 2001). Furthermore, leptin is able to stimulate LH release in pre-pubertal female rats (Dearth et al. 2000) and adult ovariectomized estrogen-primed rats (Yu et al. 1997) after a third ventricular injection of the peptide in vivo. All these results indicate that leptin plays an important role in controlling gonadotropin secretion by stimulatory hypothalamic and pituitary actions, at least in part, by modulating its receptors in a differential manner. It has been reported that plasmatic leptin levels are about $2-3 \mathrm{ng} / \mathrm{ml}$ in normally fed female rats (Watanobe \& Suda 1999, Almog et al. 2001), $0.3 \mathrm{ng} / \mathrm{ml}$ in 3-day-fasted rats (Watanobe et al. 1999) and $10 \mathrm{ng} / \mathrm{ml}$ in mildly obese humans and rats (Watanobe et al. 2001). Women with mild obesity have been reported to have three to four times higher levels of circulating leptin than subjects of normal weight (Rissanen et al. 1999). All these data suggest that the anterior pituitary seems to be insensitive to leptin concentrations higher than those found in mildly obese humans and rats. Differently, the ovary responded to both lower $(0.3 \mathrm{ng} / \mathrm{ml})$ or higher $(300-500 \mathrm{ng} / \mathrm{ml})$ leptin concentrations than the pituitary. The results obtained with progesterone concentrations in the incubation medium are consistent with previous studies using different biological models. Roman et al. (2005) reported that chronic treatment with low doses of leptin produces a stimulatory effect on the plasmatic progesterone levels, while Ricci et al. (2006) observed an inhibitory effect on the plasmatic progesterone levels in rats treated with high levels of leptin. Furthermore, Ricci et al. (2006) confirmed this result with in vitro studies where the concentration of progesterone was reduced by the presence of high levels of leptin in ovarian explants and preovulatory follicle cultures. Although the mechanism involved for such inhibitory action has not been completely clarified, it has been suggested that leptin may modulate some transcriptional factors such as StAR and P450scc (TenaSempere et al. 2001) or c-Jun (Barkan et al. 1999). In this work, we found that leptin is able to induce a biphasic effect on progesterone production. A direct inhibitory action of leptin on steroid hormone secretion has been demonstrated independently by different authors in the ovary (Spicer \& Francisco 1997, Zachow \& Magoffin 1997, Agarwal et al. 1999, Barkan et al. 1999, Zachow et al. 1999, Ghizzoni et al. 2001, Kikuchi et al. 2001) and in other tissues (Tena-Sampere et al. 2001, Cameo et al. 2003). However, findings of both stimulation and inhibition effect with different levels of leptin in ovarian cells in vitro are in agreement with observations by Ruiz-Cortés et al. (2003) who found that the effects of leptin are biphasic with regard to stimulation and inhibition of progesterone synthesis. These authors have reported that leptin modulates steroidogenesis in a biphasic manner via STAT-3.

Finally, the reason for the apparently different results obtained between in vivo and in vitro treatments with leptin is not surprising considering that i) the effective amount of leptin that reaches its target in the in vivo experiments is 
reduced due to the loss occurring in the peripheral route, thus making it difficult to be precise with the concentrations to which the tissue is exposed and ii) although the in vitro experiments are a good design to study the direct effect of many factors on their targets, we should point out that these systems lack numerous regulatory factors, and thus it is difficult to extrapolate the results. However, it is important to highlight the results obtained with the ovarian tissue, since the expression of leptin receptors was increased in rats subjected to the acute treatment with leptin and in the ovarian explants exposed to the highest concentrations.

In conclusion, all these results clearly suggest that leptin is able to modulate the expression of its own receptors in the hypothalamic-pituitary-ovarian axis in a differential way and that the positive or negative effect that leptin exerts on the ovulatory process may be dependent on this regulation.

\section{Declaration of Interest}

The authors declare that there is no conflict of interest that would prejudice the impartiality of this scientific work.

\section{Funding}

This work was supported by Grant PIP 6567 from Consejo Nacional de Investigaciones Científicas y Técnicas (CONICET) and UBACYT X006 from Universidad de Buenos Aires.

\section{Acknowledgements}

We thank Daniel Eduardo González and Carlos Hernández for their technical assistance.

\section{References}

Agarwal SK, Vogel K, Weitsman SR \& Magoffin DA 1999 Leptin antagonizes the insulin-like growth factor-1 augmentation of steroidogenesis in granulosa and theca cells of the human ovary. Journal of Clinical Endocrinology and Metabolism 84 1072-1076.

Ahima RS 2000 Leptin and the neuroendocrinology of fasting. Frontiers of Hormone Research 26 42-56.

Ahima RS \& Flier JS 2000 Leptin. Annual Review of Physiology 62 413-437.

Ahima RS, Dushay J, Flier SN, Prabakaran D \& Flier JS 1997 Leptin accelerates the onset of puberty in normal female mice. Journal of Clinical Investigation 99 391-395.

Almog B, Gold R, Tajima K, Dantes A, Salim K, Rubinstein M, Barkan D, Homburg R, Lessing JB, Nevo N et al. 2001 Leptin attenuates follicular apoptosis and accelerates the onset of puberty in immature rats. Molecular and Cellular Endocrinology 183 179-191.

Archanco M, Muruzabal FJ, Llopiz D, Garayoa M, Gomez-Ambrosi J, Fruhbeck G \& Burrell MA 2003 Leptin expression in the rat ovary depends on estrous cycle. Journal of Histochemistry and Cytochemistry 51 1269-1277.

Barkan D, Jia H, Dantes A, Vardimon L, Amsterdam A \& Rubinstein M 1999 Leptin modulates the glucocorticoid-induced ovarian steroidogenesis. Endocrinology 140 1731-1738.

Barkan D, Hurgin V, Dekel N, Amsterdam A \& Rubinstein M 2005 Leptin induces ovulation in GnRH-deficient mice. FASEB Journal 19 133-135.
Bennett PA, Lindell K, Karlsson C, Robinson IC, Carlsson LM \& Carlsson B 1998 Differential expression and regulation of leptin receptor isoforms in the rat brain: effects of fasting and oestrogen. Neuroendocrinology 67 29-36.

Bennett PA, Lindell K, Wilson C, Carlsson LM, Carlsson B \& Robinson IC 1999 Cyclical variations in the abundance of leptin receptors, but not in circulating leptin, correlate with NPY expression during the oestrous cycle. Neuroendocrinology 69 417-423.

De Biasi SN, Apfelbaum LI \& Apfelbaum ME 2001 In vitro effect of leptin on LH release by anterior pituitary glands from female rats at the time of spontaneous and steroid-induced LH surge. European Journal of Endocrinology 145 659-665.

Brannian JD, Zhao Y \& McElroy M 1999 Leptin inhibits gonadotropinstimulated granulosa cell progesterone production by antagonizing insulin action. Human Reproduction 14 1445-1448.

Cameo P, Bischof P \& Calvo JC 2003 Effect of leptin on progesterone, human chorionic gonadotropin, and interleukin-6 secretion by human term trophoblast cells in culture. Biology of Reproduction 68 472-477.

Chen H, Charlat O, Tartaglia LA, Woolf EA, Weng X, Ellis SJ, Lakey ND, Culpepper J, Moore KJ, Breitbart RE et al. 1996 Evidence that the diabetes gene encodes the leptin receptor: identification of a mutation in the leptin receptor gene in $\mathrm{db} / \mathrm{db}$ mice. Cell 84 491-495.

Chua SC Jr, Chung WK, Wu-Peng XS, Zhang Y, Liu SM, Tartaglia L \& Leibel RL 1996 Phenotypes of mouse diabetes and rat fatty due to mutations in the OB (leptin) receptor. Science 271 994-996.

Cioffi JA, Shafer AW, Zupancic TJ, Smith-Gbur J, Mikhah A, Platika D \& Snodgrass HR 1996 Novel B219/OB receptor isoforms: possible role of leptin in hematopoiesis and reproduction. Nature Medicine 2 585-589.

Cioffi JA, Van Blerkom J, Antczak M, Shafer A, Wittmer S \& Snodgrass HR 1997 The expression of leptin and its receptors in pre-ovulatory human follicles. Molecular Human Reproduction 3 467-472.

Clément K, Vaisse C, Lahlou N, Cabrol S, Pelloux V, Cassuto D, Gourmelen M, Dina C, Chambaz J, Lacorte JM et al. 1998 A mutation in the human leptin receptor gene causes obesity and pituitary dysfunction. Nature $392398-401$.

Dearth RK, Hiney JK \& Dees WL 2000 Leptin acts centrally to induce the prepubertal secretion of luteinizing hormone in the female rat. Peptides 21 387-392.

Duggal PS, Van der Hoek KH, Milner CR, Ryan NK, Armstrong DT, Magoffin DA \& Norman RJ 2000 The in vivo and in vitro effects of exogenous leptin on ovulation in the rat. Endocrinology 141 1971-1976.

Duggal PS, Ryan NK, Van der Hoek KH, Ritter LJ, Armstrong DT, Magoffin DA \& Norman RJ 2002a Effects of leptin administration and feed restriction on thecal leukocytes in the preovulatory rat ovary and the effects of leptin on meiotic maturation, granulosa cell proliferation, steroid hormone and $\mathrm{PGE}_{2}$ release in cultured rat ovarian follicles. Reproduction 123 891-898.

Duggal PS, Weitsman SR, Magoffin DA \& Norman RJ $2002 b$ Expression of the long $(\mathrm{Ob}-\mathrm{Rb})$ and short $(\mathrm{Ob}-\mathrm{R} a)$ forms of the leptin receptor throughout the oestrous cycle in the mature rat ovary. Reproduction 123 899-905.

Elmquist JK, Bjorbaek C, Ahima RS, Flier JS \& Saper CB 1998 Distributions of leptin receptor mRNA isoforms in the rat brain. Journal of Comparative Neurology 395 535-547.

Espey LL, Norris C, Forman J \& Siler-Khodr T 1989 Effect of indomethacin, cycloheximide, and aminoglutethimide on ovarian steroid and prostanoid levels during ovulation in the gonadotropin-primed immature rat. Prostaglandins 38 531-539.

Espey LL, Tanaka N, Adams RF \& Okamura H 1991 Ovarian hydroxyeicosatetraenoic acids compared with prostanoids and steroids during ovulation in rats. American Journal of Physiology 260 E163-E169.

Faletti A, Pérez Martínez S, Perotti C \& Gimeno MAF 1999a Activity of ovarian nitric oxide synthase (NOs) during ovulatory process in the rat: relationship with prostaglandin (PGs) production. Nitric Oxide 3 340-347.

Faletti AG, Mastronardi CA, Lomniczi A, Seilicovich A, Gimeno MAF, McCann SM \& Rettori V 1999 b $\beta$-Endorphin blocks luteinizing hormone-releasing hormone release by inhibiting the nitricoxidergic pathway controlling its release. PNAS 96 1722-1726. 
Fernandez-Fernandez R, Aguilar E, Tena-Sempere M \& Pinilla L 2005 Effects of polypeptide YY(3-36) upon luteinizing hormone-releasing hormone and gonadotropin secretion in prepubertal rats: in vivo and in vitro studies. Endocrinology 146 1403-1410.

Ghizzoni L, Barreca A, Mastorakos G, Furlini M, Vottero A, Ferrari B, Chrousos GP \& Bernasconi S 2001 Leptin inhibits steroid biosynthesis by human granulosa-lutein cells. Hormone and Metabolic Research 33 323-328.

Grueso E, Rocha M \& Puerta M 2001 Plasma and cerebrospinal fluid leptin levels are maintained despite enhanced food intake in progesterone-treated rats. European Journal of Endocrinology 144 659-665.

Hoggard N, Mercer JG, Rayner DV, Moar K, Trayhurn P \& Williams LM 1997 Localization of leptin receptor mRNA splice variants in murine peripheral tissues by RT-PCR and in situ hybridization. Biochemical and Biophysical Research Communications 232 383-387.

Jin L, Burguera BG, Couce ME, Scheithauer BW, Lamsan J, Eberhardt NL, Kulig E \& Lloyd RV 1999 Leptin and leptin receptor expression in normal and neoplastic human pituitary: evidence of a regulatory role for leptin on pituitary cell proliferation. Journal of Clinical Endocrinology and Metabolism 84 2903-2911.

Jin L, Zhang S, Burguera BG, Couce ME, Osamura RY, Kulig E \& Lloyd RV 2000 Leptin and leptin receptor expression in rat and mouse pituitary cells. Endocrinology 141 333-339.

Karlsson C, Lindell K, Svensson E, Bergh C, Lind P, Billig H, Carlsson LM \& Carlsson B 1997 Expression of functional leptin receptors in the human ovary. Journal of Clinical Endocrinology and Metabolism 82 4144-4148.

Kikuchi N, Andoh K, Abe Y, Yamada K, Mizunuma H \& Ibuki Y 2001 Inhibitory action of leptin on early follicular growth differs in immature and adult female mice. Biology of Reproduction 65 66-71.

Lebrethon MC, Vandersmissen E, Gerard A, Parent AS, Junien JL \& Bourguignon JP 2000 In vitro stimulation of the prepubertal rat gonadotropin-releasing hormone pulse generator by leptin and neuropeptide Y through distinct mechanisms. Endocrinology 141 1464-1469.

Lee GH, Proenca R, Montez JM, Carroll KM, Darvishzadeh JG, Lee JI \& Friedman JM 1996 Abnormal splicing of the leptin receptor in diabetic mice. Nature 379 632-635.

Martin RL, Perez E, He YJ, Dawson R Jr \& Millard WJ 2000 Leptin resistance is associated with hypothalamic leptin receptor mRNA and protein downregulation. Metabolism 49 1479-1484.

Matsuda J, Yokota I, Tsuruo Y, Murakami T, Ishimura K, Shima K \& Kuroda Y 1999 Development changes in long-form leptin receptor expression and localization in rat brain. Endocrinology 140 5233-5238.

Meli R, Pacilio M, Raso GM, Esposito E, Coppola A, Nasti A, Di Carlo C, Nappi C \& Di Carlo R 2004 Estrogen and raloxifene modulate leptin and its receptor in hypothalamus and adipose tissue from ovariectomized rats. Endocrinology 145 3115-3121.

MercerJG, Hoggard N, Williams LM, Lawrence CB, Hannah LT \& Trayhurn P 1996 Localization of leptin receptor mRNA and the long form splice variant $(\mathrm{Ob}-\mathrm{Rb})$ in mouse hypothalamus and adjacent brain regions by in situ hybridization. FEBS Letters 387 113-116.

Pal R \& Sahu A 2003 Leptin signaling in the hypothalamus during chronic central leptin infusion. Endocrinology 144 3789-3798.

Ricci AG, Di Yorio MP \& Faletti AG 2006 Inhibitory effect of leptin on the rat ovary during the ovulatory process. Reproduction 132 771-780.

Rissanen P, Makimattila S, Vehmas T, Taavitsainen M \& Rissanen A 1999 Effect of weight loss and regional fat distribution on plasma leptin concentration in obese women. International Journal of Obesity and Related Metabolic Disorders 23 645-649.

Rocha M, Grueso E \& Puerta M 2001 The anorectic effect of oestradiol does not involve changes in plasma and cerebrospinal fluid leptin concentrations in the rat. Journal of Endocrinology 171 349-354.
Roman EA, Ricci AG \& Faletti AG 2005 Leptin treatment enhances ovulation and attenuates the effects produced by food restriction. Molecular and Cellular Endocrinology 242 33-41.

Ruiz-Cortés ZT, Martel-Kennes Y, Gévry NY, Downey BR, Palin MF \& Murphy BD 2003 Biphasic effects of leptin in porcine granulosa cells. Biology of Reproduction 68 789-796.

Ryan NK, Van der Hoek KH, Robertson SA \& Norman RJ 2003 Leptin and leptin receptor expression in the rat ovary. Endocrinology 144 5006-5013.

Sone M, Nagata H, Takekoshi S \& Osamura RY 2001 Expression and localization of leptin receptor in the normal rat pituitary gland. Cell and Tissue Research 305 351-356.

Spicer LJ \& Francisco CC 1997 The adipose obese gene product, leptin: evidence of a direct inhibitory role in ovarian function. Endocrinology 138 3374-3379.

Strobel A, Issad T, Camoin L, Ozata M \& Strosberg AD 1998 A leptin missense mutation associated with hypogonadism and morbid obesity. Nature Genetics 18 213-215.

Tartaglia LA 1997 The leptin receptor. Journal of Biological Chemistry 272 6093-6096.

Tartaglia LA, Dembski M, Weng X, Deng N, Culpepper J, Devos R, Richards GJ, Campfield LA, Clark FT, Deeds J et al. 1995 Identification and expression cloning of a leptin receptor, Ob-R. Cell 83 1263-1271.

Tena-Sempere M, Manna PR, Zhang F-P, Pinilla L, González LC, Diéguez C, Huhtaniemi I \& Aguilar E 2001 Molecular mechanisms of leptin action in adult rat testis: potential targets for leptin-induced inhibition of steroidogenesis and pattern of leptin receptor messenger ribonucleic acid expression. Journal of Endocrinology 170 413-423.

Watanobe H 2002 Leptin directly acts within the hypothalamus to stimulate gonadotropin-releasing hormone secretion in vivo in rats. Journal of Physiology 545 255-268.

Watanobe H \& Suda T 1999 A detailed study on the role of sex steroid milieu in determining plasma leptin concentrations in adult male and female rats. Biochemical and Biophysical Research Communications 259 56-59.

Watanobe H, Suda T, Wikberg JE \& Schioth HB 1999 Evidence that physiological levels of circulating leptin exert a stimulatory effect on luteinizing hormone and prolactin surges in rats. Biochemical and Biophysical Research Communications 263 162-165.

Watanobe H, Yoneda M, Kohsaka A, Kakizaki Y, Suda T \& Schioth HB 2001 Normalization of circulating leptin levels by fasting improves the reproductive function in obese OLETF female rats. Neuropeptides 35 45-49.

Yu WH, Kimura M, Walczewska A, Karanth S \& McCann SM 1997 Role of leptin in hypothalamic-pituitary function. PNAS 94 1023-1028.

Zachow RJ \& Magoffin DA 1997 Direct intraovarian effects of leptin: impairment of the synergistic action of insulin-like growth factor-I on follicle-stimulating hormone-dependent estradiol-17 $\beta$ production by rat ovarian granulosa cells. Endocrinology 138 847-850.

Zachow RJ, Weitsman SR \& Magoffin DA 1999 Leptin impairs the synergistic stimulation by transforming growth factor- $\beta$ of follicle-stimulating hormone-dependent aromatase activity and messenger ribonucleic acid expression in rat ovarian granulosa cells. Biology of Reproduction 61 1104-1109.

Zamorano PL, Mahesh VB, De Sevilla LM, Chorich LP, Bhat GK \& Rrann DW 1997 Expression and localization of the leptin receptor in endocrine and neuroendocrine tissues of the rat. Neuroendocrinology 65 223-228.

Received in final form 7 May 2008

Accepted 30 May 2008

Made available online as an Accepted Preprint 30 May 2008 